\title{
Current View on Osteogenic Differentiation Potential of Mesenchymal Stromal Cells Derived from Placental Tissues
}

\author{
Gabriela Kmiecik • Valentina Spoldi • Antonietta Silini • \\ Ornella Parolini
}

Published online: 9 November 2014

(C) The Author(s) 2014. This article is published with open access at Springerlink.com

\begin{abstract}
Mesenchymal stromal cells (MSC) isolated from human term placental tissues possess unique characteristics, including their peculiar immunomodulatory properties and their multilineage differentiation potential. The osteogenic differentiation capacity of placental MSC has been widely disputed, and continues to be an issue of debate. This review will briefly discuss the different MSC populations which can be obtained from different regions of human term placenta, along with their unique properties, focusing specifically on their osteogenic differentiation potential. We will present the strategies used to enhance osteogenic differentiation potential in vitro, such as through the selection of subpopulations more prone to differentiate, the modification of the components of osteo-inductive medium, and even mechanical stimulation. Accordingly, the applications of three-dimensional environments in vitro and in vivo, such as non-synthetic, polymerbased, and ceramic scaffolds, will also be discussed, along with results obtained from pre-clinical studies of placental MSC for the regeneration of bone defects and treatment of bone-related diseases.
\end{abstract}

Keywords Human placenta $\cdot$ Mesenchymal stromal cells (MSC) - Amniotic membrane - Chorionic membrane · Umbilical cord · Wharton's jelly · Decidua · Differentiation . Osteogenesis

Mesenchymal stromal cells (MSC) were described within the bone marrow (BM) in 1968 by Friedenstein and colleagues

Gabriela Kmiecik and Valentina Spoldi contributed equally to this work.

G. Kmiecik $\cdot$ V. Spoldi $\cdot$ A. Silini $\cdot$ O. Parolini $(\bowtie)$

Centro di Ricerca E. Menni, Fondazione Poliambulanza-Istituto

Ospedaliero, Via Bissolati, 57, 25124 Brescia, Italy

e-mail: ornella.parolini@poliambulanza.it
[1]. Since then, many other sources have been identified such as adipose tissue [reviewed in [2,3]], cord blood [reviewed in [4]], and one which has recently attracted much attention is human term placenta [reviewed in [5]], mainly for its easy, non-invasive procurement and abundant tissue, and also for the remarkable immunomodulatory capabilities of MSC isolated from placental tissues. It is well known that the different sources of MSC present different capabilities to differentiate toward mature lineages [6]. This review will focus on data reported thus far regarding the osteogenic differentiation potential of mesenchymal stromal cells deriving from placental tissues.

\section{MSC Derived from Different Placental Regions}

Human placenta is composed of a fetal part, including the amnion, chorion, umbilical cord, and a maternal part, termed decidua. Within these components different cell subpopulations with mesenchymal characteristics may be isolated, and as established by the consensus of the First International Workshop on Placenta-Derived Stem Cells, they are referred to amniotic mesenchymal stromal cells (hAMSC) and chorion mesenchymal stromal cells (hCMSC) [5]. MSC can also be isolated from umbilical cord (UC) and have been referred to as either hUC-MSC or Wharton's jelly (hWJ)-MSC [7], and from the maternal decidua (hDMSC) [8]. Commonly used methods for MSC isolation are enzymatic digestion employing collagenase and DNase, dispase, trypsin, or explant culture [5,9]. In general, placental tissues-derived mesenchymal stromal cells as MSC from other sources present spindle-shape, elongated morphology, adherence to plastic and CFU capacity [10]. 
MSC derived from different regions of human placenta, similar to BM-MSC, express typical mesenchymal antigens such as CD90, CD73, CD105, CD13, CD44, CD29, CD166, CD117, HLA-A, $-\mathrm{B},-\mathrm{C}$, and lack hematopoietic markers CD34, CD45, CD14, endothelial marker CD31, costimulatory molecules CD80, CD86, CD40, CD40L, and HLA-DR [11-14]. Some reports have suggested the presence of pluripotent markers Sox-2, OCT-4, Nanog, and SSEA-4 in placental MSC [8, 15-17]. Differentiation potential toward the mesodermal lineage, and specifically toward the adipogenic, chondrogenic, and osteogenic lineages, has been reported for Wharton's jelly, decidua, and fetal membrane (FM)-derived MSC $[5,8,9]$. Others have also reported in vitro differentiation potential toward ectodermal (neurogenic), as well as endodermal (hepatogenic) lineage of FM-derived MSC and hWJ-MSC [18-20].

Placental tissue MSC also present low expression of MHC class II and (as mentioned above) classical co-stimulatory molecules, features that have made them to be considered as poor antigen presenting cells [21]. However, caution is warranted considering that the same interpretation has been used for BM-MSC, but previous reports have shown the capability of these cells to induce an immune response [22, 23]. Moreover, it has been reported that MSC derived from different placental tissues can interact with and modulate a variety of immune cells [24]. The ability to suppress lymphocyte proliferation induced by mitogens or alloantigens $[25,26]$, and the capacity to block maturation of monocytes into dendritic cells $[27,28]$, are examples of their immunomodulatory effects. Furthermore, immunomodulatory molecules, such as HLA-G, B7-H1 and B7-H3, and prostaglandins, secreted from early and term placenta, which have important implications in the fetal maternal tolerance mechanisms, have been reported to be expressed not only in the trophoblast but also in the FMderived cells, hWJ-MSC and hDMSC [[29-32] and reviewed in [14]] and therefore, very likely play a role in the immunomodulatory capacities of these cells [33].

\section{In Vitro Osteogenic Potential}

As previously stated, mesenchymal cells derived from different placental tissues differentiate toward "classical" mesodermal lineages $[5,9]$. Herein, we summarize the results obtained from approximately 150 published papers which investigate the osteogenic differentiation of mesenchymal cells derived from amnion, chorion, umbilical cord, and decidua (Tables 1, 2, and 3). We will use hAMSC, hCMSC, hUC-MSC (or hWJ-MSC), and hDMSC to describe the MSC from specified placental tissues, according to the information provided by the authors, while we will use hPD-MSC to refer to placenta derived-mesenchymal stromal cells in general, and when the specific region of placenta used was not indicated. Since it was not possible to be fully comprehensive in the limited space available, we apologize in advance to authors whose work was not cited in this review.

\section{In Vitro Two-Dimensional Osteogenic Differentiation}

In this section we will focus on data describing in vitro twodimensional osteogenic differentiation, and approaches to improve the outcomes, such as selection of subpopulations and modification of culture conditions, and the results obtained.

\section{Selection of Subpopulations}

Considering the heterogeneity of the mesenchymal stromal population within the placental regions, some authors attempted to select for subpopulations more prone to differentiate towards the osteogenic lineage (Table 1). For example, positive selection using Frizzled-9 (FDZ9), as based on information available on BM-MSC [34], together with $\mathrm{CD} 10$ and $\mathrm{CD} 26$ resulted in a subpopulation of hAMSC with elevated expression levels of osteocalcin (OC), increased number of cells with positive alkaline phosphatase (ALP) activity, and higher number of calcium-rich nodules in comparison with unselected cells, altogether suggesting increased differentiation potential of the selected cells [35]. On the other hand, decreased osteogenic differentiation was observed when hAMSC and hCMSC were selected based upon CD105 positivity [36]. Moreover, a $\mathrm{CD} 44^{+} / \mathrm{CD} 73^{+} / \mathrm{CD} 105^{-}$subpopulation of hAMSC showed higher bone matrix mineralization and stronger expression of secreted protein acidic and rich in cysteine (SPARC) and osteopontin (OPN), two markers commonly associated to mineralization, than $\mathrm{CD} 44^{+} /$ $\mathrm{CD}^{+} 3^{+} / \mathrm{CD} 105^{+}$cells, while no significant differences were observed for collagen type I-alpha 1 (COLIA1) and OC expression [15]. CD271 has also been investigated as a potential selection marker for MSC selection. Previously, selection for CD271 positivity was shown to identify a BM-MSC subpopulation more prone to differentiate into the osteogenic lineage [37]. More recently, our group applied this same selection in hAMSC and hCMSC populations, where clearly enhanced osteogenic differentiation in the CD271-enriched fractions were observed [10]. It was also reported that side-population derived from hAMSC showed osteogenic differentiation potential [38], and that both $\mathrm{CD} 106^{+}$and $\mathrm{CD} 106^{-}$fractions from hCMSC demonstrated similar ability to differentiate into the osteogenic lineage [39].

As previously mentioned, hPD-MSC share the majority of features with BM-MSC, however some differences have been reported. For example, increased expression of CD146 on BM-MSC in comparison to hPD-MSC, together with that of ALP assessed before differentiation, has been shown to correlate with improved osteogenic differentiation capacity [40]. 


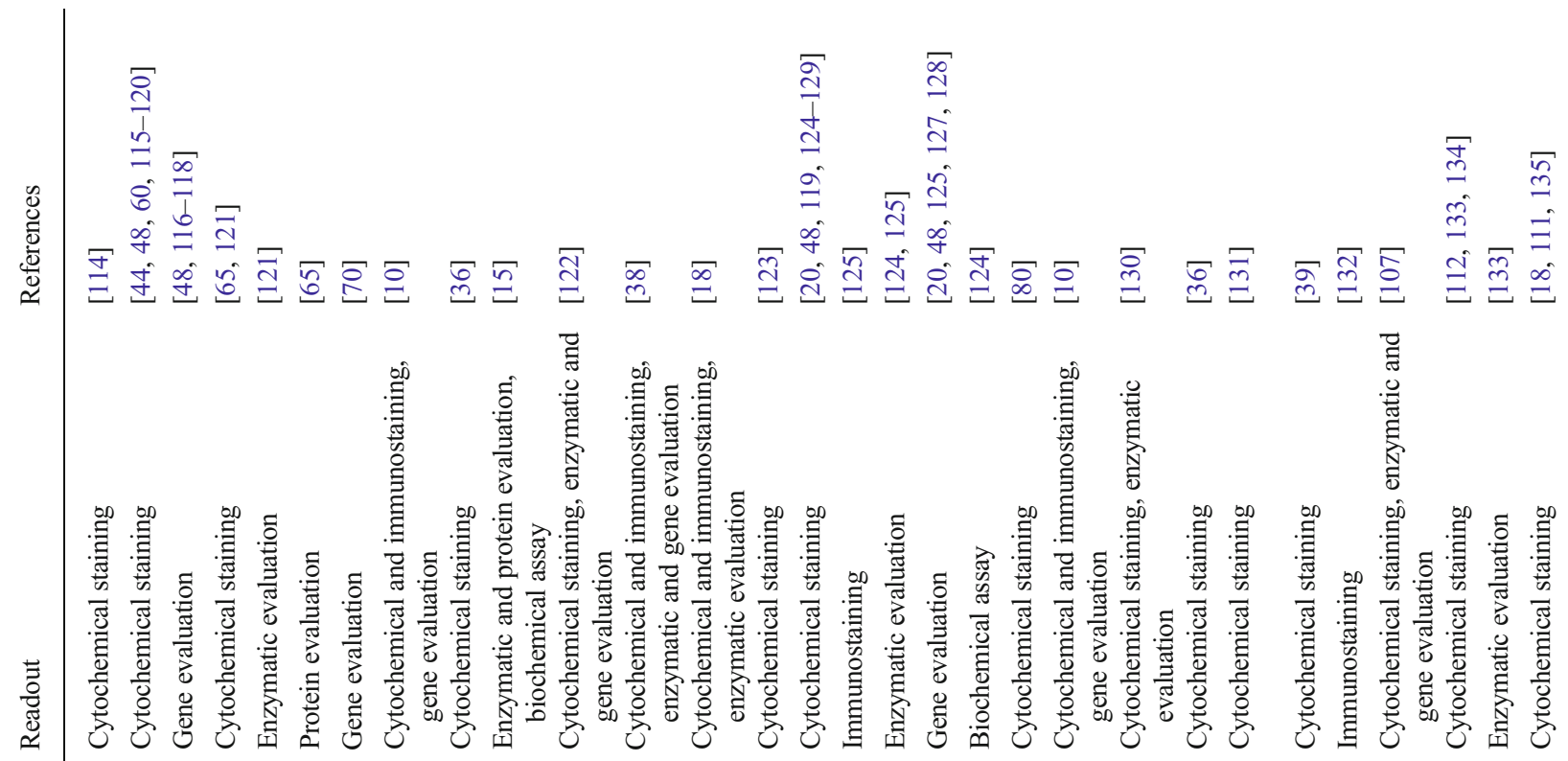

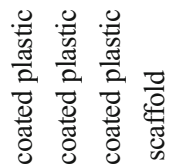

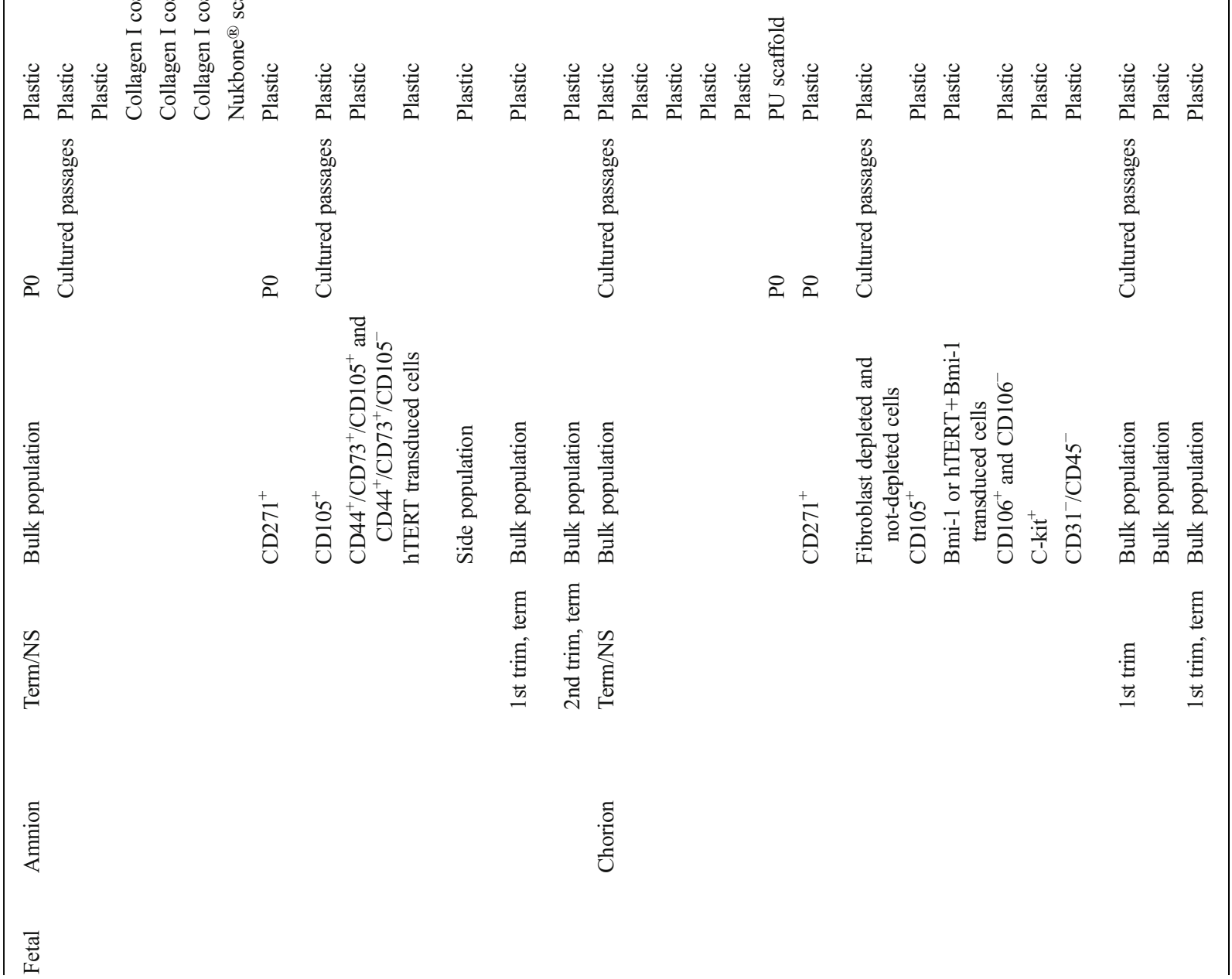




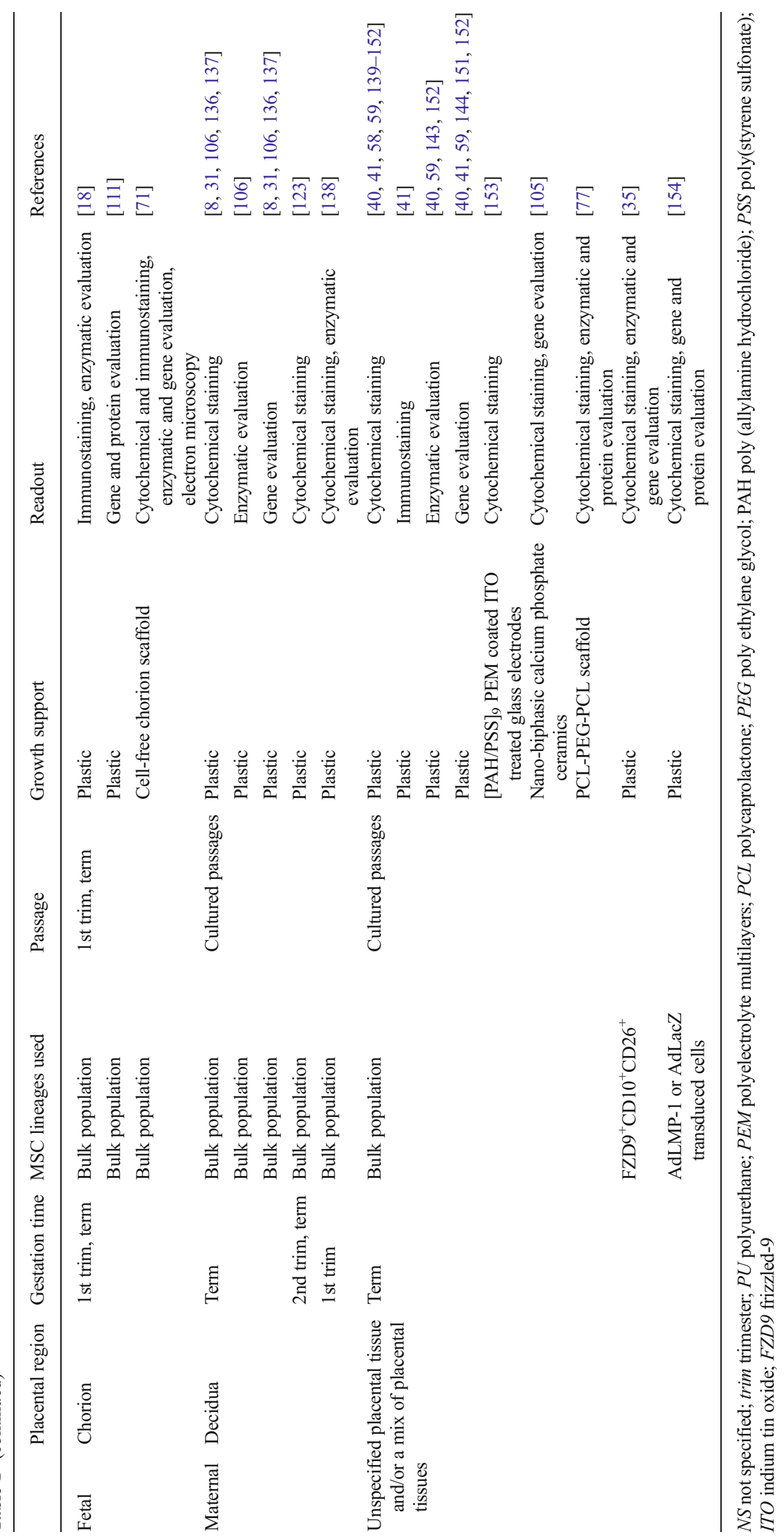


Transcriptomic analysis of hPD-MSC showed differential expression of osteogenesis related genes, assessed either prior to (Runx2, Twist2), or after (BMP2, osteomodulin, SFRP1, SFRP4) osteoinduction and differentiation [41].

\section{Composition of Differentiation Media}

Attempts to enhance osteogenic differentiation have been made by modifying the composition of the osteogenicinductive medium (i.e. different supplements) [reviewed in [42, 43]]. Osteogenic differentiation medium is generally composed of basal medium (e.g. DMEM) supplemented with $10 \%$ FBS, dexamethasone, $\beta$-glycerol phosphate, ascorbic acid, $1 \alpha, 25$-dihydroxyvitamin D3 $[18,44-46]$. Osteogenic differentiation of hWJ-MSC was observed at early and late passages (15-20) after culturing in either DMEM low glucose, DMEM high glucose, DMEM/F12 or DMEM-KO as a basal media, with the latter inducing even higher calcification [47]. FBS has been investigated as a factor which could influence osteogenic potential. FBS removal from the culture media was found to result in the absence of mineralization in hAMSC, hCMSC, BM-MSC, and adipose tissuederived stromal cells (ASC) [48]. Accordingly, the presence of FBS has been shown to enhance osteogenicassociated marker ALP and bone sialoprotein (BSP) expression in BM-MSC and ASC, while low or no expression was found in fetal-derived MSC in both culture conditions [48]. Regarding the use of xenobiotic-free medium for a more clinically-relevant approach, some studies have also investigated the use of platelet-rich plasma (PRP) [49], platelet lysate [50-54] or platelet concentrate [40] as a culture media supplement. UCBderived PRP has also been used as a growth factor to assist in vivo osteogenic differentiation $[55,56]$.

Other supplements have been used in the attempt to boost osteogenic differentiation, such as osteogenic proteins (rhBMP-2) [57], osteoactivin [58], and chemical entities such as bortezomib [59] and 5-aminoimidazole4-carboxamide-1- $\beta$-riboside (AICAR) [60]. Moreover, the inflammatory microenvironment, common to degenerative diseases in which MSC are used as cell-therapy, has also been investigated for its impact on osteogenic differentiation. For instance, pretreatment of hWJ-MSC with an inflammatory cytokine cocktail (IL- $1 \beta$, IFN- $\gamma$, TNF- $\alpha$ and IFN- $\alpha$ ) increased differentiation into osteoblasts similarly to BM-MSC and ASC, although in absence of stimulation with inflammatory cytokines, the osteogenic differentiation capability of hWJ-MSC was lower than that of BM-MSC and ASC [61]. Moreover, TLR3 and TLR4 ligation did not affect hWJ-MSC, while it enhanced ASC osteogenic potential [61].

\section{Mechanical Stimulation}

Mechanical stimulation mimicking the movement presented in in vivo settings has been reported as another approach to enhance in vitro MSC osteogenic differentiation. Cyclic uniaxial stimulation, one of the most widely used mechanical stimulations in vitro, was shown to accelerate osteogenic differentiation of BMMSC [62]. Mechanical stimulation provided by the Flexcell system, potentiated the osteogenic differentiation of hUC-MSC (in the presence of osteogenic supplements), as indicated by an increase of the osteogenic gene (osteoprotegerin, OC, OPN, osteonectin, collagen I (Coll I), Coll III and vimentin), and protein (BSP and vimentin) expression [63].

In conclusion, differentiation toward the osteogenic lineage is evident in the majority of in vitro studies, however there are reports showing weak $[36,40,41,48,61]$ or even lack of osteogenic differentiation $[64,65]$.

\section{In Vitro Three-Dimensional Osteogenic Differentiation}

The number of studies investigating three-dimensional environment for bone tissue formation is constantly increasing. So far, most of the studies present in literature investigate $\mathrm{hWJ}$ MSC rather than fetal-membrane derived MSC, suggesting a growing interest in this specific placental cell population. In this section, we will present data describing the osteogenic differentiation on different types of three-dimensional constructs, namely non-synthetic, polymer-based, and ceramic scaffolds (see also Tables 1 and 2).

\section{Osteogenic Differentiation on Non-Synthetic Scaffolds}

Generally, synthetic biomaterials are employed for the preparation of scaffolds to support osteogenic differentiation, although some groups have attempted to use non-synthetic biomaterials in order to enhance biocompatibility and biodegradability. For example, commonly used non-synthetic scaffolds are collagens, which are abundant in the osteocyte environment, have high mechanical strength, and have been shown to stimulate MSC to differentiate into osteoblast-like cells, altogether initiating new bone formation [66, 67]. Cultivation of hUC-MSC, and BM-MSC, on a collagen I/III gel has been shown to lead to deposition of hydroxyapatite (HA)/ calcium crystals and to an active shift of the collagen I/III ratio in favor of collagen I, the main component of bone extracellular matrix (ECM). Moreover, production of other ECM proteins like collagen IV, laminin and glycosaminoglycans (GAGs), was also observed in a manner comparable to functional osteocytes and osteoblasts [68].

Natural biomaterials have also been shown to be able to support proliferation and osteogenic differentiation of 
Table 2 Summary of studies describing in vitro osteogenic differentiation of term hUC-MSC and hWJ-MSC at passages

\begin{tabular}{|c|c|c|c|}
\hline MSC lineages used & Growth support & Readout & References \\
\hline \multirow[t]{31}{*}{ Bulk population } & \multirow[t]{6}{*}{ Plastic } & Cytochemical staining & $\begin{array}{l}{[17,20,47,52,55,57,61,64,76} \\
\quad 92,96,98,155-179]^{*}\end{array}$ \\
\hline & & Immunostaining & {$[52,57,96,156,175,180]$} \\
\hline & & Enzymatic evaluation & $\begin{array}{c}{[17,52,57,61,76,96,98,157-159,} \\
162,173,177,180-183]^{* *}\end{array}$ \\
\hline & & Gene evaluation & $\begin{array}{c}{[17,20,57,61,64,92,98,155} \\
\quad 158-160,162,164,165,167 \\
\quad 171,173,175,177,180,184]^{*}\end{array}$ \\
\hline & & Protein evaluation & {$[57,98,184]$} \\
\hline & & Biochemical assay & {$[17,76,170,173]$} \\
\hline & $\begin{array}{l}\text { Rod-like-nHA and flake-like-micro-HA } \\
\text { coatings on } \mathrm{Mg} \text {-Zn-Ca alloy substrates }\end{array}$ & $\begin{array}{l}\text { Cytochemical and immunostaining, } \\
\text { enzymatic and gene evaluation }\end{array}$ & {$[185]$} \\
\hline & $\begin{array}{l}\text { Type I atelocollagen-coated Bioflex }{ }^{\circledR} \\
\text { plate stimulated with Flexcell system }\end{array}$ & Gene and protein evaluation & {$[63]$} \\
\hline & \multirow[t]{2}{*}{ Fibronectin coating } & $\begin{array}{l}\text { Cytochemical and immunostaining, } \\
\text { enzymatic, gene and protein evaluation }\end{array}$ & {$[186]$} \\
\hline & & $\begin{array}{l}\text { Cytochemical and immunostaining, } \\
\text { electron microscopy }\end{array}$ & {$[187]$} \\
\hline & Collagen I coating & Cytochemical staining, protein evaluation & {$[65]$} \\
\hline & PAAM substrates & Cytochemical staining, gene evaluation & {$[188]$} \\
\hline & Porcine urinary bladder matrix scaffold & $\begin{array}{l}\text { Cytochemical and immunostaining, } \\
\text { enzymatic and gene evaluation, } \\
\text { electron microscopy, spectroscopy }\end{array}$ & [69] \\
\hline & \multirow[t]{2}{*}{ Collagen scaffold } & $\begin{array}{l}\text { Cytochemical staining, enzymatic } \\
\text { evaluation }\end{array}$ & [189] \\
\hline & & $\begin{array}{l}\text { Cytochemical and immunostaining, gene } \\
\text { evaluation and electron microscopy }\end{array}$ & {$[68]$} \\
\hline & \multirow[t]{4}{*}{ PGA and derivatives scaffold } & $\begin{array}{l}\text { Cytochemical staining, enzymatic and } \\
\text { gene evaluation }\end{array}$ & {$[79,81]$} \\
\hline & & Protein evaluation & [81] \\
\hline & & Biochemical assay & {$[78,79]$} \\
\hline & & Electron microscopy & [79] \\
\hline & \multirow[t]{3}{*}{ PCL and derivatives scaffold } & $\begin{array}{l}\text { Cytochemical staining, enzymatic and } \\
\text { gene evaluation, electron microscopy }\end{array}$ & {$[75,76]$} \\
\hline & & Immunostaining & [75] \\
\hline & & Spectroscopy & {$[76]$} \\
\hline & \multirow[t]{2}{*}{ PLLA scaffold } & $\begin{array}{l}\text { Cytochemical staining, protein and gene } \\
\text { evaluation }\end{array}$ & {$[82,83]$} \\
\hline & & Immunostaining & {$[82]$} \\
\hline & $\begin{array}{l}\text { Nano-biphasic calcium phosphate } \\
\text { ceramics }\end{array}$ & Cytochemical staining, gene evaluation & [105] \\
\hline & 45S5 Bioglass-based scaffold & Cytochemical staining, protein evaluation & {$[190]$} \\
\hline & \multirow[t]{5}{*}{ CPC scaffold and derivatives } & Cytochemical staining & $\begin{array}{l}{[45,46,84,85,87,89-91,93-95,} \\
109]\end{array}$ \\
\hline & & Enzymatic evaluation & {$[45,46,88-91]$} \\
\hline & & Gene evaluation & {$[45,46,85-89,91,93-95,109]$} \\
\hline & & Electron microscopy & {$[86,88,89]$} \\
\hline & & Spectroscopy & {$[88,89]$} \\
\hline $\begin{array}{l}\text { Bulk population and } \mathrm{HSP} 90 \beta \\
\text { transfected cells }\end{array}$ & Plastic & $\begin{array}{l}\text { Cytochemical staining, enzymatic and } \\
\text { gene evaluation }\end{array}$ & [108] \\
\hline Lentiviral-transduced cells & Plastic & Enzymatic and gene evaluation & [191] \\
\hline Osx-transfected MSC & Plastic & Enzymatic and gene evaluation & [97] \\
\hline
\end{tabular}

$P C L$ polycaprolactone; $P A A M$ polyacrylamide hydrogel; $P G A$ polyglycolic acid; $P L L A$ poly(L-Lactic acid); $C P C$ calcium phosphate cement; $n H A$ nanohydroxyapatite; Osx osterix

* Reference 92: hUC-MSC were encapsulated within alginate microbeads, oxidized alginate microbeads, and oxidized alginate-fibrin microbeads

** Reference 182: UCX ${ }^{\circledR}$ cells: human stem cells derived from the umbilical cord tissue (Wharton's jelly) 
hPD-MSC [69, 70]. Evidence of osteogenic differentiation, as suggested by higher gene expression of Runx2, OPN, Coll I, ALP activity and mineralized matrix deposition, were provided when hWJ-MSC were seeded on an extracellular matrix scaffold (porcine urinary bladder derived matrix) in the presence of differentiation medium [69]. Moreover, osteoinductive effects of Nukbone ${ }^{\circledR}$ (NBK), a human bone biomimetic material from bovine bone matrix, were observed in hAMSC without the application of differentiation medium, as demonstrated by $\mathrm{OC}$ and Runx 2 gene expression [70]. Interestingly, human chorionic membrane has also been used as cell-free extracellular matrix scaffold for osteogenic differentiation. Up-regulation of OC and OPN gene expression, and positive immunohistochemical staining for OC, OPN and Runx2, but not Coll I, together with increased $\mathrm{Ca}^{2+}$ concentrations, characteristic for advanced mineralization, have been documented [71]. The amniotic membrane, which has been largely used in the field of tissue engineering as a biological scaffold [reviewed in [72] and [73]], has been recently demonstrated to act as a natural cell substrate for the osteogenic differentiation of amniotic membrane-derived cells without cell isolation, leaving cells residing within their natural environment [74].

\section{Osteogenic Differentiation on Polymer-Based Scaffolds}

Osteogenic differentiation of hPD-MSC has been widely assessed on scaffolds containing polycaprolactone (PCL) and/or its derivatives [75-77]. Mineralization and upregulation of osteogenic genes were observed in MSC derived from umbilical cord when collagen and HA [75] or $\beta$-tricalcium phosphate (TCP) [76] were added to PCL scaffold, even though hUC-MSC demonstrated lower osteogenic differentiation potential than fetal BM-MSC [76]. Culture of hPD-MSC on PCEC (PCL-poly(ethylene glycol)(PEG)-PCL) copolymer revealed osteoblast differentiation as demonstrated by mineral deposition, expression of OPN and OC, and increased ALP activity compared to hPD-MSC differentiated on plastic plates [77]. Mineralization and osteogenic gene expression were also observed on hUC-MSC seeded on polyglycolic acid (PGA) and derivatives (poly(lactide-co-glycolide), PLGA) scaffolds [78, 79]. Greater ALP and OC expression, together with higher ALP activity and OC content of hUCMSC cultured on nanoHA/chitosan(CS)/PLGA scaffold was observed, as compared to PLGA, nanoHA/PLGA and CS/PLGA [79]. Polyurethanes (PU) are another example of polymers applied for supporting osteogenic differentiation, however, only a small amount of calcium deposition has been observed when chorion-MSC were cultured on PU foam with induction medium [80].

Some strategies have been designed for osteochondral tissue engineering in order to simultaneously obtain osteo- and chondrogenic differentiation on the same construct [81, 82]. For example, recently, an in vitro study reported that microsphere-based scaffolds constructed to release TGF- $\beta 1$ and BMP-2 (factors known for inducing chondrogenesis and osteogenesis, respectively), with a gradual and continuous transition in the release of TGF- $\beta 1$ and BMP-2 from one side of the scaffold to the other, was able to promote osteogenic differentiation of hUC-MSC and BM-MSC [81]. A significant increase was observed in cell number, GAGs and collagen content, and ALP activity in the gradient scaffold [81]. The ability of poly(LLactic acid) (PLLA) scaffolds to support osteogenic differentiation of hUC-MSC has been previously demonstrated [83]. In a follow-up study by the same group, a further strategy was implemented by sandwiching hUC-MSC between chondrogenic and osteogenic PLLA scaffolds and then suturing them together [82]. Osteochondral composites with hUC-MSC exhibited the best integration and transition of ECM between the layers, while composites without cells presented better distribution and stronger staining of calcium, Coll II and aggrecan [82].

\section{Osteogenic Differentiation on Ceramic Scaffolds}

The use of ceramic scaffolds as support for osteogenic differentiation is widely recognized. For the most part, hPDMSC have been investigated with calcium phosphate cement (CPC)-based scaffolds, since this type of scaffold has been shown to be an injectable and resorbable bioceramic. Using hWJ-MSC, efforts have been made to enhance physical and mechanical properties [45, 84-87], cell distribution within the scaffold [46, 88-92], cell adhesion to the scaffold surface [46, 84, 93-95], and in vitro osteogenic differentiation.

hUC-MSC have been seeded on traditional CPC, and attachment, proliferation and differentiation toward the osteogenic lineage have been demonstrated [86], and even improved differentiation when CPC was supplemented with different biofunctional agents (fibronectin, fibronectin-like engineered polymer protein (FEPP), arginylglycyl-aspartic acid (RGD), Geltrex, platelet concentrate), fibers (collagen, PLGA fibers) [84, 93, 94], or mannitol [45]. In addition, alginate hydrogel beads have been used to protect hUC-MSC against mixing and injection forces and to favor the distribution within the scaffold, while maintaining the osteogenic differentiation capabilities of cells [86, 88, 89, 91]. Moreover, as the cells are encapsulated within the microbeads, rapid microbead degradation followed by cell release is required. Improvement of the rate of microbead degradation, in accordance with the release of hUC-MSC, has been developed maintaining cell differentiation potential toward the osteogenic lineage $[46,92,95]$. Indeed, released hUC-MSC underwent osteogenic differentiation as indicated by upregulation of osteogenic gene expression (ALP, OC, Coll 
I), ALP activity and mineral synthesis [46, 95]. Interestingly, improvement of osteogenic differentiation was achieved by encapsulation of pre-differentiated hUC-MSC, or by delivery of osteogenic medium, instead of BMP-2, into the microbeads together with hUC-MSC. The results showed that each of these approaches allowed hUC-MSC to be successfully differentiated into the osteogenic lineage [90].

\section{In Vivo Osteogenic Potential}

Currently, the number of studies describing in vivo applications of hPD-MSC for bone defect restoration is increasing (Table 3). Proof of principle studies of the in vivo osteogenic potential of hPD-MSC may be achieved using subcutaneous injection of experimental constructs to induce ectopic bone formation and to assess the feasibility of different biomaterials. For example, different types of constructs supporting osteogenic differentiation, such as nano-HA/CS/poly(lactide-coglycolide) (nHA/CS/PLGA), have been investigated using hUC-MSC. The application of nHA/collagen/ PLA, nHA/PLGA, CS/PLGA, or nHA/CS/PLGA seeded with hUC-MSC indicated immature bone tissue formation after subcutaneous implantation into nude mice [55, 79, 96]. Enhanced bone formation was observed on PLGA scaffolds also when osterix-transfected hUCMSC were used, a transcription factor known for its role in osteoblast differentiation and bone formation, together with up-regulated mRNA expression of ALP, OC, OPN and Coll I when compared to non-transfected hUC-MSC/PLGA and mock-hUC-MSC/PLGA controls [97]. In vivo subcutaneous implantation of MSC from different sources on PCL-TCP scaffolds has been shown to result in superior osteogenic potential of fetal BMMSC, when compared to adult BM-MSC, perinatal hUC-MSC, and ASC [76].

In addition, considering the clinical application of MSC, the use of autologous tissues to avoid/minimize the probability of infections and immune response to biomaterials has been investigated. Recently, umbilical cord blood (UCB)derived fibrin as a scaffold for hUC-MSC, UCB-derived platelet-rich-plasma (UCB-PRP) as a source of growth factors, and UCB-derived serum for hUC-MSC culture were studied in vivo after subcutaneous implantation. Although no defined bone tissue in vivo was seen, ectopic calcification was observed [56]. Application of hUC-MSC have also been studied in dental regeneration in terms of periodontal tissue healing, important to increase success rate of autotransplantation of teeth. In vivo osteogenic differentiation of hUC-MSC on dentine disc showed the ability to form cementum-like deposits after subcutaneous implantation suggesting that hUC-MSC may be useful in this field [98].
hPD-MSC for Regeneration of Bone Defects

Most of the studies regarding in vivo bone regeneration investigate femur or cranial fractures. Critical-size calvarial defects are widely employed to study bone healing in animal models, mostly rodents, because the calvaria are large plates that facilitate the creation of defects, implantation of grafts and the analysis (histology, imaging) of reconstruction [99, 100]. Segmental defects in long bones are also widely used as clinically relevant models [101-104].

The number of studies investigating hPD-MSC in femur fractures is increasing. Femur defects have been treated with hPD-MSC used in combination with nanosized biphasic $\mathrm{Ca} / \mathrm{P}$ ceramics and led to complete recovery of the defect with no graft rejection or inflammation process [105]. Good integration of the material with surrounding host tissues and newly formed bone was observed, together with expression of human Runx 2 mRNA, indicating that implanted MSC were able to survive and promote in vivo osteogenesis [105].

In vitro attempts have been made to select for a subpopulation more prone to differentiate into osteogenic lineage in in vivo models. Using a method based on time-gradient attachment, hDMSC seeded into PLGA scaffolds have shown significant bone formation 20 weeks after transplantation into full-thickness calvaria defects, as confirmed by histological and immunohistochemical assays [106]. Transplantation of both FZD9 (CD349)-positive and -negative hCMSC in femur defects in mice resulted in facilitating new bone calcification in fractured femurs [107].

In vitro knock down of HSP90 $\beta$ (a cell proliferation related protein) on hWJ-MSC revealed enhanced osteogenic differentiation. Following experiments in in vivo segmental bone defects resulted in more prominent bone tissue in comparison to hWJ-MSC without HSP90 $\beta$ knockdown [108].

The in vivo osteogenic potential of hUC-MSC has been compared to adult MSC from BM [109] and adipose tissue, and perinatal UCB [102] using critical-sized cranial [109] and femoral defect models in rat [102]. Based on quantitative assessment, the authors concluded that there were no significant differences between fetal and adult MSC $[102,109]$.

Treatment of non-union fractures has rarely been investigated. Transplantation for non-union fractures in a rat model using hUC-MSC in presence of blood plasma resulted in new bone formation and disappearing cortical gaps, suggesting a possible role of hUC-MSC in bone healing [110].

\section{hPD-MSC for the Treatment of Bone-Related Diseases}

hPD-MSC have also been investigated in vivo in other bonerelated diseases, such as osteogenesis imperfecta (OI) and multiple myeloma (MM).

In a comparison study investigating the characteristics of hCMSC obtained from first trimester with those obtained from 


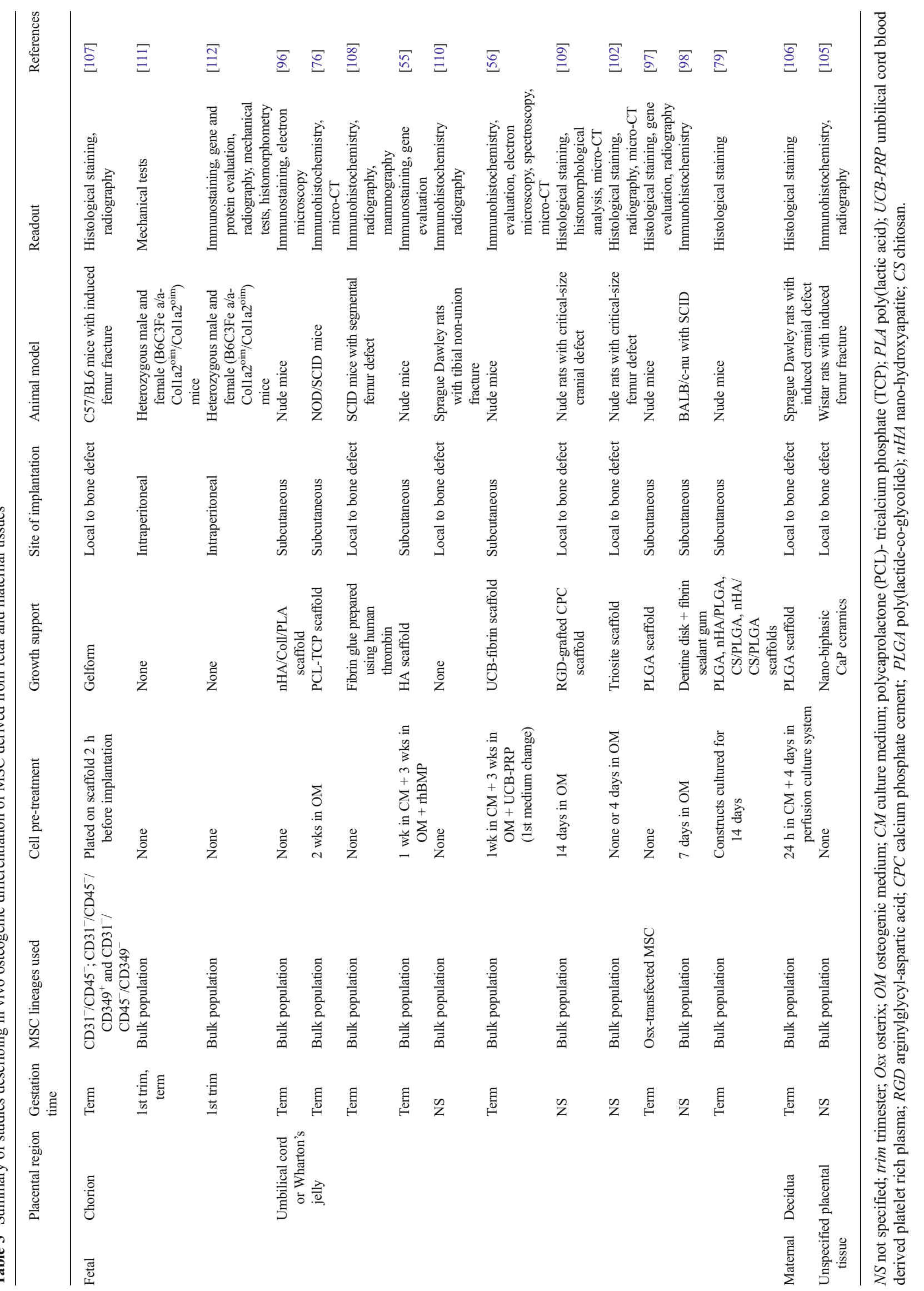


term placenta, intraperitoneal injection of early (first trimester) hCMSC in a murine model of OI (oim) was more efficient in improving overall bone quality, as shown by a reduction of fractures, increased bone volume and bone plasticity, when compared to term hCMSC [111]. Moreover, transplanted first trimester hCMSC underwent differentiation into functional osteoblasts as confirmed by COL1A2 protein expression in the femoral bones of oim [112].

Multiple myeloma is a malignancy giving rise to osteolytic bone disease and increased fractures. An interesting study has shown that hPD-MSC were able to suppress MM-induced bone lesions, and also tumor growth in bone, through osteoclast formation and stimulation of endogenous osteoblastogenesis when injected into myelomatous osteolytic lesions [113].

\section{Conclusions}

In conclusion, the majority of in vitro studies support the potential of hPD-MSC to differentiate into the osteogenic lineage, suggesting their possible use in regenerative medicine to repair osteo-related defects. A large amount of evidence has been provided based on in vitro calcium deposition and/or gene expression, each of which point toward different stages of differentiation potential. In vivo studies, even if in some cases are very encouraging, are still somewhat preliminary and are mostly based on the use of one region of placenta, namely Wharton's jelly.

Hence, in order to apply hPD-MSC for bone regeneration, further investigations should be focused on the selection of the most prone subpopulation, pre-committing hPD-MSC prior to in vivo use, and selection of the most appropriate support for differentiation.

Acknowledgments The authors would like to thank Fondazione Poliambulanza-Istituto Ospedaliero of Brescia, Cariplo Foundation (Grant n.2012-0842), and Competitiveness ROP ERDF 2007-2013 of the Region of Lombardy (Regional Operational Programme of the European Regional Development Fund - Progetto NUTEC NUove TECnologie ID n.30263049) for their support.

Conflict of Interests The authors state they have no conflict of interest.

Open Access This article is distributed under the terms of the Creative Commons Attribution License which permits any use, distribution, and reproduction in any medium, provided the original author(s) and the source are credited.

\section{References}

1. Friedenstein, A. J., Petrakova, K. V., Kurolesova, A. I., \& Frolova, G. P. (1968). Heterotopic of bone marrow. analysis of precursor cells for osteogenic and hematopoietic tissues. Transplantation, $6(2), 230-47$.

2. Mizuno, H., Tobita, M., \& Uysal, A. C. (2012). Concise review: adipose-derived stem cells as a novel tool for future regenerative medicine. Stem Cells, 30(5), 804-10.

3. Bourin, P., Bunnell, B. A., Casteilla, L., Dominici, M., Katz, A. J., March, K. L., et al. (2013). Stromal cells from the adipose tissuederived stromal vascular fraction and culture expanded adipose tissue-derived stromal/stem cells: a joint statement of the international federation for adipose therapeutics and science (IFATS) and the international society for cellular therapy (ISCT). Cytotherapy, 15(6), 641-8.

4. Flynn, A., Barry, F., \& O'Brien, T. (2007). UC blood-derived mesenchymal stromal cells: an overview. Cytotherapy, 9(8), 717-26.

5. Parolini, O., Alviano, F., Bagnara, G. P., Bilic, G., Buhring, H. J., Evangelista, M., et al. (2008). Concise review: isolation and characterization of cells from human term placenta: outcome of the first international workshop on placenta derived stem cells. Stem Cells, 26(2), 300-11.

6. Huang, Y. C., Parolini, O., La Rocca, G., \& Deng, L. (2012). Umbilical cord versus bone marrow-derived mesenchymal stromal cells. Stem Cells and Development, 21(15), 2900-3.

7. Corrao, S., La Rocca, G., Lo Iacono, M., Corsello, T., Farina, F., \& Anzalone, R. (2013). Umbilical cord revisited: from Wharton's jelly myofibroblasts to mesenchymal stem cells. Histology and Histopathology, 28(10), 1235-44.

8. Macias, M. I., Grande, J., Moreno, A., Dominguez, I., Bornstein, R., \& Flores, A. I. (2010). Isolation and characterization of true mesenchymal stem cells derived from human term decidua capable of multilineage differentiation into all 3 embryonic layers. American Journal of Obstetrics and Gynecology, 203(5), 495 e9-495 e23.

9. Can, A., \& Karahuseyinoglu, S. (2007). Concise review: human umbilical cord stroma with regard to the source of fetus-derived stem cells. Stem Cells, 25(11), 2886-95.

10. Soncini, M., Vertua, E., Gibelli, L., Zorzi, F., Denegri, M., Albertini, A., et al. (2007). Isolation and characterization of mesenchymal cells from human fetal membranes. Journal of Tissue Engineering and Regenerative Medicine, 1(4), 296-305.

11. Bernardo, M. E., Emons, J. A., Karperien, M., Nauta, A. J., Willemze, R., Roelofs, H., et al. (2007). Human mesenchymal stem cells derived from bone marrow display a better chondrogenic differentiation compared with other sources. Connective Tissue Research, 48(3), 132-40.

12. Manuelpillai, U., Moodley, Y., Borlongan, C. V., \& Parolini, O. (2011). Amniotic membrane and amniotic cells: potential therapeutic tools to combat tissue inflammation and fibrosis? Placenta, 32(Suppl 4), S320-5.

13. Insausti, C. L., Blanquer, M., Garcia-Hernandez, A. M., Castellanos, G., \& Moraleda, J. M. (2014). Amniotic membranederived stem cells: immunomodulatory properties and potential clinical application. Stem Cells Cloning, 7, 53-63.

14. La Rocca, G., Corrao, S., Lo Iacono, M., Corsello, T., Farina, F., \& Anzalone, R. (2012). Novel immunomodulatory markers expressed by human WJ-MSC: an updated review in regenerative and reparative medicine. The Open Tissue Engineering and Regenerative Medicine Journal, 5(1), 50-58.

15. Leyva-Leyva, M., Barrera, L., Lopez-Camarillo, C., ArriagaPizano, L., Orozco-Hoyuela, G., Carrillo-Casas, E. M., et al. (2013). Characterization of mesenchymal stem cell subpopulations from human amniotic membrane with dissimilar osteoblastic potential. Stem Cells and Development, 22(8), 1275-87.

16. Jiang, G., Di Bernardo, J., Delong, C. J., Monteiro da Rocha, A., O'Shea, K. S., \& Kunisaki, S. M. (2014). Induced pluripotent stem cells from human placental chorion for perinatal tissue engineering applications. Tissue Engineering. Part C, Methods, 20, 731-40. 
17. Jo, C. H., Kim, O. S., Park, E. Y., Kim, B. J., Lee, J. H., Kang, S. B., et al. (2008). Fetal mesenchymal stem cells derived from human umbilical cord sustain primitive characteristics during extensive expansion. Cell and Tissue Research, 334(3), 423-33.

18. Portmann-Lanz, C. B., Schoeberlein, A., Huber, A., Sager, R., Malek, A., Holzgreve, W., et al. (2006). Placental mesenchymal stem cells as potential autologous graft for pre- and perinatal neuroregeneration. American Journal of Obstetrics and Gynecology, 194(3), 664-73.

19. Paldino, E., Cenciarelli, C., Giampaolo, A., Milazzo, L., Pescatori, M., Hassan, H. J., et al. (2014). Induction of dopaminergic neurons from human Wharton's jelly mesenchymal stem cell by forskolin. Journal of Cellular Physiology, 229(2), 232-44.

20. Kim, M. J., Shin, K. S., Jeon, J. H., Lee, D. R., Shim, S. H., Kim, J. K., et al. (2011). Human chorionic-plate-derived mesenchymal stem cells and Wharton's jelly-derived mesenchymal stem cells: a comparative analysis of their potential as placenta-derived stem cells. Cell and Tissue Research, 346(1), 53-64.

21. Weiss, M. L., Anderson, C., Medicetty, S., Seshareddy, K. B., Weiss, R. J., VanderWerff, I., et al. (2008). Immune properties of human umbilical cord Wharton's jelly-derived cells. Stem Cells, 26(11), 2865-74.

22. Uccelli, A., Moretta, L., \& Pistoia, V. (2006). Immunoregulatory function of mesenchymal stem cells. European Journal of Immunology, 36(10), 2566-73.

23. Eliopoulos, N., Stagg, J., Lejeune, L., Pommey, S., \& Galipeau, J. (2005). Allogeneic marrow stromal cells are immune rejected by MHC class I- and class II-mismatched recipient mice. Blood, 106(13), 4057-65.

24. Parolini, O., Alviano, F., Bergwerf, I., Boraschi, D., De Bari, C., De Waele, P., et al. (2010). Toward cell therapy using placenta-derived cells: disease mechanisms, cell biology, preclinical studies, and regulatory aspects at the round table. Stem Cells and Development, 19(2), 143-54.

25. Bailo, M., Soncini, M., Vertua, E., Signoroni, P. B., Sanzone, S., Lombardi, G., et al. (2004). Engraftment potential of human amnion and chorion cells derived from term placenta. Transplantation, $78(10), 1439-48$.

26. Magatti, M., De Munari, S., Vertua, E., Gibelli, L., Wengler, G. S., \& Parolini, O. (2008). Human amnion mesenchyme harbors cells with allogeneic T-cell suppression and stimulation capabilities. Stem Cells, 26(1), 182-92.

27. Magatti, M., De Munari, S., Vertua, E., Nassauto, C., Albertini, A., Wengler, G. S., et al. (2009). Amniotic mesenchymal tissue cells inhibit dendritic cell differentiation of peripheral blood and amnion resident monocytes. Cell Transplantation, 18(8), 899-914.

28. Magatti, M., Caruso, M., De Munari, S., Vertua, E., De, D., Manuelpillai, U., et al. (2014). Human amniotic membranederived mesenchymal and epithelial cells exert different effects on monocyte-derived dendritic cell differentiation and function. Cell Transplant.

29. Lee, J. M., Jung, J., Lee, H. J., Jeong, S. J., Cho, K. J., Hwang, S. G., et al. (2012). Comparison of immunomodulatory effects of placenta mesenchymal stem cells with bone marrow and adipose mesenchymal stem cells. International Immunopharmacology, 13(2), 219-24.

30. Kim, D. W., Staples, M., Shinozuka, K., Pantcheva, P., Kang, S. D., \& Borlongan, C. V. (2013). Wharton's jelly-derived mesenchymal stem cells: phenotypic characterization and optimizing their therapeutic potential for clinical applications. International Journal of Molecular Sciences, 14(6), 11692-712.

31. Kanematsu, D., Shofuda, T., Yamamoto, A., Ban, C., Ueda, T., Yamasaki, M., et al. (2011). Isolation and cellular properties of mesenchymal cells derived from the decidua of human term placenta. Differentiation, 82(2), 77-88.

32. Rossi, D., Pianta, S., Magatti, M., Sedlmayr, P., \& Parolini, O. (2012). Characterization of the conditioned medium from amniotic membrane cells: prostaglandins as key effectors of its immunomodulatory activity. PLoS ONE, 7(10), e46956.

33. Silini, A., Parolini, O., Huppertz, B., \& Lang, I. (2013). Soluble factors of amnion-derived cells in treatment of inflammatory and fibrotic pathologies. Current Stem Cell Research \& Therapy, 8(1), 6-14.

34. Battula, V. L., Bareiss, P. M., Treml, S., Conrad, S., Albert, I., Hojak, S., et al. (2007). Human placenta and bone marrow derived MSC cultured in serum-free, b-FGF-containing medium express cell surface frizzled-9 and SSEA-4 and give rise to multilineage differentiation. Differentiation, 75(4), 279-91.

35. Battula, V. L., Treml, S., Abele, H., \& Buhring, H. J. (2008). Prospective isolation and characterization of mesenchymal stem cells from human placenta using a frizzled-9-specific monoclonal antibody. Differentiation, 76(4), 326-36.

36. Bacenkova, D., Rosocha, J., Tothova, T., Rosocha, L., \& Sarissky, M. (2011). Isolation and basic characterization of human term amnion and chorion mesenchymal stromal cells. Cytotherapy, 13(9), 1047-56.

37. Quirici, N., Soligo, D., Bossolasco, P., Servida, F., Lumini, C., \& Deliliers, G. L. (2002). Isolation of bone marrow mesenchymal stem cells by anti-nerve growth factor receptor antibodies. Experimental Hematology, 30(7), 783-91.

38. Kobayashi, M., Yakuwa, T., Sasaki, K., Sato, K., Kikuchi, A., Kamo, I., et al. (2008). Multilineage potential of side population cells from human amnion mesenchymal layer. Cell Transplantation, 17(3), 291-301.

39. Yang, Z. X., Han, Z. B., Ji, Y. R., Wang, Y. W., Liang, L., Chi, Y., et al. (2013). CD106 identifies a subpopulation of mesenchymal stem cells with unique immunomodulatory properties. PLOS ONE, 8(3), e59354.

40. Pilz, G. A., Ulrich, C., Ruh, M., Abele, H., Schafer, R., Kluba, T., et al. (2011). Human term placenta-derived mesenchymal stromal cells are less prone to osteogenic differentiation than bone marrowderived mesenchymal stromal cells. Stem Cells and Development, 20(4), 635-46.

41. Ulrich, C., Rolauffs, B., Abele, H., Bonin, M., Nieselt, K., Hart, M. L., et al. (2013). Low osteogenic differentiation potential of placenta-derived mesenchymal stromal cells correlates with low expression of the transcription factors Runx2 and Twist2. Stem Cells and Development, 22(21), 2859-72.

42. Heng, B. C., Cao, T., Stanton, L. W., Robson, P., \& Olsen, B. (2004). Strategies for directing the differentiation of stem cells into the osteogenic lineage in vitro. Journal of Bone and Mineral Research, 19(9), 1379-94.

43. Lindenmair, A., Hatlapatka, T., Kollwig, G., Hennerbichler, S., Gabriel, C., Wolbank, S., et al. (2012). Mesenchymal stem or stromal cells from amnion and umbilical cord tissue and their potential for clinical applications. Cells, 1(4), 1061-88.

44. Alviano, F., Fossati, V., Marchionni, C., Arpinati, M., Bonsi, L., Franchina, M., et al. (2007). Term amniotic membrane is a high throughput source for multipotent mesenchymal stem cells with the ability to differentiate into endothelial cells in vitro. $B M C$ Developmental Biology, 7, 11.

45. Tang, M., Weir, M. D., \& Xu, H. H. (2012). Mannitol-containing macroporous calcium phosphate cement encapsulating human umbilical cord stem cells. Journal of Tissue Engineering and Regenerative Medicine, 6(3), 214-24.

46. Chen, W., Zhou, H., Weir, M. D., Bao, C., \& Xu, H. H. (2012). Umbilical cord stem cells released from alginate-fibrin microbeads inside macroporous and biofunctionalized calcium phosphate cement for bone regeneration. Acta Biomaterialia, $8(6), 2297-306$.

47. Nekanti, U., Rao, V. B., Bahirvani, A. G., Jan, M., Totey, S., \& Ta, M. (2010). Long-term expansion and pluripotent marker array 
analysis of Wharton's jelly-derived mesenchymal stem cells. Stem Cells and Development, 19(1), 117-30.

48. Cavallo, C., Cuomo, C., Fantini, S., Ricci, F., Tazzari, P. L., Lucarelli, E., et al. (2011). Comparison of alternative mesenchymal stem cell sources for cell banking and musculoskeletal advanced therapies. Journal of Cellular Biochemistry, 112(5), 1418-30.

49. Amable, P. R., Teixeira, M. V., Carias, R. B., Granjeiro, J. M., \& Borojevic, R. (2014). Mesenchymal stromal cell proliferation, gene expression and protein production in human platelet-rich plasmasupplemented media. PLOS ONE, 9(8), e104662.

50. Zeddou, M., Briquet, A., Relic, B., Josse, C., Malaise, M. G., Gothot, A., et al. (2010). The umbilical cord matrix is a better source of mesenchymal stem cells (MSC) than the umbilical cord blood. Cell Biology International, 34(7), 693-701.

51. Capelli, C., Gotti, E., Morigi, M., Rota, C., Weng, L., Dazzi, F., et al. (2011). Minimally manipulated whole human umbilical cord is a rich source of clinical-grade human mesenchymal stromal cells expanded in human platelet lysate. Cytotherapy, 13(7), 786-801.

52. Marmotti, A., Mattia, S., Bruzzone, M., Buttiglieri, S., Risso, A., Bonasia, D. E., et al. (2012). Minced umbilical cord fragments as a source of cells for orthopaedic tissue engineering: an in vitro study. Stem Cells International, 2012, 326813.

53. Poloni, A., Maurizi, G., Serrani, F., Mancini, S., Discepoli, G., Tranquilli, A. L., et al. (2012). Human AB serum for generation of mesenchymal stem cells from human chorionic villi: comparison with other source and other media including platelet lysate. Cell Proliferation, 45(1), 66-75.

54. Martins, J. P., Santos, J. M., Almeida, J. M., Filipe, M. A., de Almeida, M. V., Almeida, S. C., et al. (2014). Towards an advanced therapy medicinal product based on mesenchymal stromal cells isolated from the umbilical cord tissue: quality and safety data. Stem Cell Research \& Therapy, 5(1), 9.

55. Baba, K., Yamazaki, Y., Ikemoto, S., Aoyagi, K., Takeda, A., \& Uchinuma, E. (2012). Osteogenic potential of human umbilical cord-derived mesenchymal stromal cells cultured with umbilical cord blood-derived autoserum. Journal of Cranio-Maxillo-Facial Surgery, 40(8), 768-72.

56. Baba, K., Yamazaki, Y., Ishiguro, M., Kumazawa, K., Aoyagi, K., Ikemoto, S., et al. (2013). Osteogenic potential of human umbilical cord-derived mesenchymal stromal cells cultured with umbilical cord blood-derived fibrin: a preliminary study. Journal of CranioMaxillo-Facial Surgery, 41(8), 775-82.

57. Hou, T., Xu, J., Wu, X., Xie, Z., Luo, F., Zhang, Z., et al. (2009). Umbilical cord Wharton's jelly: a new potential cell source of mesenchymal stromal cells for bone tissue engineering. Tissue Engineering Part A, 15(9), 2325-34.

58. Raynaud, C. M., Maleki, M., Lis, R., Ahmed, B., Al-Azwani, I., Malek, J., et al. (2012). Comprehensive characterization of mesenchymal stem cells from human placenta and fetal membrane and their response to osteoactivin stimulation. Stem Cells International, 2012,658356

59. Sanvoranart, T., Supokawej, A., Kheolamai, P., U-pratya, Y., Klincumhom, N., Manochantr, S., et al. (2014). Bortezomib enhances the osteogenic differentiation capacity of human mesenchymal stromal cells derived from bone marrow and placental tissues. Biochemical and Biophysical Research Communications, 447(4), 580-5.

60. Wu, W., Ye, Z., Zhou, Y., \& Tan, W. S. (2011). AICAR, a small chemical molecule, primes osteogenic differentiation of adult mesenchymal stem cells. International Journal of Artificial Organs, 34(12), 1128-36.

61. Raicevic, G., Najar, M., Pieters, K., De Bruyn, C., Meuleman, N., Bron, D., et al. (2012). Inflammation and Toll-like receptor ligation differentially affect the osteogenic potential of human mesenchymal stromal cells depending on their tissue origin. Tissue Engineering Part A, 18(13-14), 1410-8.
62. Wiesmann, A., Buhring, H. J., Mentrup, C., \& Wiesmann, H. P. (2006). Decreased CD90 expression in human mesenchymal stem cells by applying mechanical stimulation. Head \& Face Medicine, 2, 8.

63. Kang, M. N., Yoon, H. H., Seo, Y. K., \& Park, J. K. (2012). Effect of mechanical stimulation on the differentiation of cord stem cells. Connective Tissue Research, 53(2), 149-59.

64. Bosch, J., Houben, A. P., Radke, T. F., Stapelkamp, D., Bunemann, E., Balan, P., et al. (2012). Distinct differentiation potential of "MSC" derived from cord blood and umbilical cord: are cordderived cells true mesenchymal stromal cells? Stem Cells and Development, 21(11), 1977-88.

65. Sudo, K., Kanno, M., Miharada, K., Ogawa, S., Hiroyama, T., Saijo, K., et al. (2007). Mesenchymal progenitors able to differentiate into osteogenic, chondrogenic, and/or adipogenic cells in vitro are present in most primary fibroblast-like cell populations. Stem Cells, 25(7), 1610-7.

66. Zhou, J., Xu, C., Wu, G., Cao, X., Zhang, L., Zhai, Z., et al. (2011). In vitro generation of osteochondral differentiation of human marrow mesenchymal stem cells in novel collagen-hydroxyapatite layered scaffolds. Acta Biomaterialia, 7(11), 3999-4006.

67. Reichert, J. C., Heymer, A., Berner, A., Eulert, J., \& Noth, U. (2009). Fabrication of polycaprolactone collagen hydrogel constructs seeded with mesenchymal stem cells for bone regeneration. Biomedical Materials, 4(6), 065001.

68. Schneider, R. K., Puellen, A., Kramann, R., Raupach, K., Bornemann, J., Knuechel, R., et al. (2010). The osteogenic differentiation of adult bone marrow and perinatal umbilical mesenchymal stem cells and matrix remodelling in three-dimensional collagen scaffolds. Biomaterials, 31(3), 467-80.

69. Penolazzi, L., Mazzitelli, S., Vecchiatini, R., Torreggiani, E., Lambertini, E., Johnson, S., et al. (2012). Human mesenchymal stem cells seeded on extracellular matrix-scaffold: viability and osteogenic potential. Journal of Cellular Physiology, 227(2), 857-66.

70. Rodriguez-Fuentes, N., Rodriguez-Hernandez, A. G., Enriquez-Jimenez, J., Alcantara-Quintana, L. E., FuentesMera, L., Pina-Barba, M. C., et al. (2013). Nukbone(R) promotes proliferation and osteoblastic differentiation of mesenchymal stem cells from human amniotic membrane. Biochemical and Biophysical Research Communications, 434(3), 676-80.

71. Mohr, S., Portmann-Lanz, C. B., Schoeberlein, A., Sager, R., \& Surbek, D. V. (2010). Generation of an osteogenic graft from human placenta and placenta-derived mesenchymal stem cells. Reproductive Sciences, 17(11), 1006-15.

72. Niknejad, H., Peirovi, H., Jorjani, M., Ahmadiani, A., Ghanavi, J., $\&$ Seifalian, A. M. (2008). Properties of the amniotic membrane for potential use in tissue engineering. European Cells \& Materials, 15, 88-99.

73. Parolini, O., Soncini, M., Evangelista, M., \& Schmidt, D. (2009). Amniotic membrane and amniotic fluid-derived cells: potential tools for regenerative medicine? Regenerative Medicine, 4(2), 275-91.

74. Lindenmair, A., Wolbank, S., Stadler, G., Meinl, A., PeterbauerScherb, A., Eibl, J., et al. (2010). Osteogenic differentiation of intact human amniotic membrane. Biomaterials, 31(33), 8659-65.

75. Gauthaman, K., Venugopal, J. R., Yee, F. C., Biswas, A., Ramakrishna, S., \& Bongso, A. (2011). Osteogenic differentiation of human Wharton's jelly stem cells on nanofibrous substrates in vitro. Tissue Engineering Part A, 17(1-2), 71-81.

76. Zhang, Z. Y., Teoh, S. H., Chong, M. S., Schantz, J. T., Fisk, N. M., Choolani, M. A., et al. (2009). Superior osteogenic capacity for bone tissue engineering of fetal compared with perinatal and adult mesenchymal stem cells. Stem Cells, 27(1), 126-37.

77. Zhang, D., Tong, A., Zhou, L., Fang, F., \& Guo, G. (2012). Osteogenic differentiation of human placenta-derived mesenchymal stem cells 
(PMSCs) on electrospun nanofiber meshes. Cytotechnology, 64(6), 701-10.

78. Wang, L., Dormer, N. H., Bonewald, L. F., \& Detamore, M. S. (2010). Osteogenic differentiation of human umbilical cord mesenchymal stromal cells in polyglycolic acid scaffolds. Tissue Engineering Part A, 16(6), 1937-48.

79. Wang, F., Zhang, Y. C., Zhou, H., Guo, Y. C., \& Su, X. X. (2014). Evaluation of in vitro and in vivo osteogenic differentiation of nano-hydroxyapatite/chitosan/poly(lactide-coglycolide) scaffolds with human umbilical cord mesenchymal stem cells. Journal of Biomedical Materials Research. Part A, 102(3), 760-8.

80. Bertoldi, S., Fare, S., Denegri, M., Rossi, D., Haugen, H. J., Parolini, O., et al. (2010). Ability of polyurethane foams to support placenta-derived cell adhesion and osteogenic differentiation: preliminary results. Journal of Materials Science Materials in Medicine, 21(3), 1005-11.

81. Dormer, N. H., Singh, M., Wang, L., Berkland, C. J., \& Detamore, M. S. (2010). Osteochondral interface tissue engineering using macroscopic gradients of bioactive signals. Annals of Biomedical Engineering, 38(6), 2167-82.

82. Wang, L., Zhao, L., \& Detamore, M. S. (2011). Human umbilical cord mesenchymal stromal cells in a sandwich approach for osteochondral tissue engineering. Journal of Tissue Engineering and Regenerative Medicine, 5(9), 712-21.

83. Wang, L., Singh, M., Bonewald, L. F., \& Detamore, M. S. (2009). Signalling strategies for osteogenic differentiation of human umbilical cord mesenchymal stromal cells for 3D bone tissue engineering. Journal of Tissue Engineering and Regenerative Medicine, 3(5), 398-404.

84. Thein-Han, W., \& Xu, H. H. (2011). Collagen-calcium phosphate cement scaffolds seeded with umbilical cord stem cells for bone tissue engineering. Tissue Engineering Part A, 17(23-24), 2943-54.

85. TheinHan, W., Weir, M. D., Simon, C. G., \& Xu, H. H. (2013). Non-rigid calcium phosphate cement containing hydrogel microbeads and absorbable fibres seeded with umbilical cord stem cells for bone engineering. Journal of Tissue Engineering and Regenerative Medicine, 7(10), 777-87.

86. Xu, H. H., Zhao, L., Detamore, M. S., Takagi, S., \& Chow, L. C. (2010). Umbilical cord stem cell seeding on fast-resorbable calcium phosphate bone cement. Tissue Engineering Part A, 16(9), 2743-53.

87. Zhou, H., Weir, M. D., \& Xu, H. H. (2011). Effect of cell seeding density on proliferation and osteodifferentiation of umbilical cord stem cells on calcium phosphate cement-fiber scaffold. Tissue Engineering Part A, 17(21-22), 2603-13.

88. Xu, H. H., Zhao, L., \& Weir, M. D. (2010). Stem cell-calcium phosphate constructs for bone engineering. Journal of Dental Research, 89(12), 1482-8.

89. Zhao, L., Weir, M. D., \& Xu, H. H. (2010). Human umbilical cord stem cell encapsulation in calcium phosphate scaffolds for bone engineering. Biomaterials, 31(14), 3848-57.

90. Zhao, L., Tang, M., Weir, M. D., Detamore, M. S., \& Xu, H. H. (2011). Osteogenic media and rhBMP-2-induced differentiation of umbilical cord mesenchymal stem cells encapsulated in alginate microbeads and integrated in an injectable calcium phosphate-chitosan fibrous scaffold. Tissue Engineering Part A, 17(7-8), 969-79.

91. Zhao, L., Weir, M. D., \& Xu, H. H. (2010). An injectable calcium phosphate-alginate hydrogel-umbilical cord mesenchymal stem cell paste for bone tissue engineering. Biomaterials, 31(25), 6502-10.

92. Zhou, H., \& Xu, H. H. (2011). The fast release of stem cells from alginate-fibrin microbeads in injectable scaffolds for bone tissue engineering. Biomaterials, 32(30), 7503-13.

93. Bao, C., Chen, W., Weir, M. D., Thein-Han, W., \& Xu, H. H. (2011). Effects of electrospun submicron fibers in calcium phosphate cement scaffold on mechanical properties and osteogenic differentiation of umbilical cord stem cells. Acta Biomaterialia, 7(11), 4037-44.
94. Thein-Han, W., Liu, J., \& Xu, H. H. (2012). Calcium phosphate cement with biofunctional agents and stem cell seeding for dental and craniofacial bone repair. Dental Materials, 28(10), 1059-70.

95. Zhou, H., Chen, W., Weir, M. D., \& Xu, H. H. (2012). Biofunctionalized calcium phosphate cement to enhance the attachment and osteodifferentiation of stem cells released from fastdegradable alginate-fibrin microbeads. Tissue Engineering Part A, 18(15-16), 1583-95.

96. Diao, Y., Ma, Q., Cui, F., \& Zhong, Y. (2009). Human umbilical cord mesenchymal stem cells: osteogenesis in vivo as seed cells for bone tissue engineering. Journal of Biomedical Materials Research. Part A, 91(1), 123-31.

97. Wang, B., Huang, S., Pan, L., \& Jia, S. (2013). Enhancement of bone formation by genetically engineered human umbilical cord-derived mesenchymal stem cells expressing osterix. Oral Surgery, Oral Medicine, Oral Pathology and Oral Radiology, 116(4), e221-9.

98. Li, Y., Hou, R., Wang, Y., Lu, B., Zhang, J., Feng, X., et al. (2014). Fundamental study of application of umbilical cord mesenchymal stem cells to the periodontium to aid healing after autotransplantation of teeth. British Journal of Oral and Maxillofacial Surgery, 52(6), $501-6$.

99. Zhang, Y., Wu, C., Friis, T., \& Xiao, Y. (2010). The osteogenic properties of $\mathrm{CaP} /$ silk composite scaffolds. Biomaterials, 31(10), 2848-56.

100. Zong, C., Xue, D., Yuan, W., Wang, W., Shen, D., Tong, X., et al. (2010). Reconstruction of rat calvarial defects with human mesenchymal stem cells and osteoblast-like cells in poly-lactic-co-glycolic acid scaffolds. European Cells \& Materials, 20, 109-20.

101. Chiu, L. H., Lai, W. F., Chang, S. F., Wong, C. C., Fan, C. Y., Fang, C. L., et al. (2014). The effect of type II collagen on MSC osteogenic differentiation and bone defect repair. Biomaterials, 35(9), 2680-91.

102. Jo, C. H., Yoon, P. W., Kim, H., Kang, K. S., \& Yoon, K. S. (2013). Comparative evaluation of in vivo osteogenic differentiation of fetal and adult mesenchymal stem cell in rat critical-sized femoral defect model. Cell and Tissue Research, 353(1), 41-52.

103. Kumar, S., \& Ponnazhagan, S. (2012). Mobilization of bone marrow mesenchymal stem cells in vivo augments bone healing in a mouse model of segmental bone defect. Bone, 50(4), 1012-8.

104. Fan, Z. X., Lu, Y., Deng, L., Li, X. Q., Zhi, W., Li-Ling, J., et al. (2012). Placenta- versus bone-marrow-derived mesenchymal cells for the repair of segmental bone defects in a rabbit model. FEBS Journal, 279(13), 2455-65.

105. Reddy, S., Wasnik, S., Guha, A., Kumar, J. M., Sinha, A., \& Singh, S. (2013). Evaluation of nano-biphasic calcium phosphate ceramics for bone tissue engineering applications: in vitro and preliminary in vivo studies. Journal of Biomaterials Applications, 27(5), 565-75.

106. Yuan, W., Zong, C., Huang, Y., Gao, Y., Shi, D., Chen, C., et al. (2012). Biological, immunological and regenerative characteristics of placenta-derived mesenchymal stem cell isolated using a time-gradient attachment method. Stem Cell Research, 9(2), $110-23$.

107. Tran, T. C., Kimura, K., Nagano, M., Yamashita, T., Ohneda, K., Sugimori, H., et al. (2011). Identification of human placenta-derived mesenchymal stem cells involved in re-endothelialization. Journal of Cellular Physiology, 226(1), 224-35.

108. Kuo, H. C., Chiu, C. C., Chang, W. C., Sheen, J. M., Ou, C. Y., Kuo, H. C., et al. (2011). Use of proteomic differential displays to assess functional discrepancies and adjustments of human bone marrowand Wharton jelly-derived mesenchymal stem cells. Journal of Proteome Research, 10(3), 1305-15.

109. Chen, W., Liu, J., Manuchehrabadi, N., Weir, M. D., Zhu, Z., \& Xu, H. H. (2013). Umbilical cord and bone marrow mesenchymal stem cell seeding on macroporous calcium phosphate for bone regeneration in rat cranial defects. Biomaterials, 34(38), 9917-25. 
110. Qu, Z., Guo, L., Fang, G., Cui, Z., Guo, S., \& Liu, Y. (2012). Biological characteristics and effect of human umbilical cord mesenchymal stem cells (hUC-MSCs) grafting with blood plasma on bone regeneration in rats. Cell Biochemistry and Biophysics, 63(2), 171-81.

111. Jones, G. N., Moschidou, D., Puga-Iglesias, T. I., Kuleszewicz, K., Vanleene, M., Shefelbine, S. J., et al. (2012). Ontological differences in first compared to third trimester human fetal placental chorionic stem cells. PLoS ONE, 7(9), e43395.

112. Jones, G. N., Moschidou, D., Abdulrazzak, H., Kalirai, B. S., Vanleene, M., Osatis, S., et al. (2013). Potential of human fetal chorionic stem cells for the treatment of osteogenesis imperfecta. Stem Cells and Development, 23(3), 262-76.

113. Li, X., Ling, W., Pennisi, A., Wang, Y., Khan, S., Heidaran, M., et al. (2011). Human placenta-derived adherent cells prevent bone loss, stimulate bone formation, and suppress growth of multiple myeloma in bone. Stem Cells, 29(2), 263-73.

114. Bilic, G., Zeisberger, S. M., Mallik, A. S., Zimmermann, R., \& Zisch, A. H. (2008). Comparative characterization of cultured human term amnion epithelial and mesenchymal stromal cells for application in cell therapy. Cell Transplantation, 17(8), 955-68.

115. Kim, J., Kang, H. M., Kim, H., Kim, M. R., Kwon, H. C., Gye, M. C., et al. (2007). Ex vivo characteristics of human amniotic membranederived stem cells. Cloning and Stem Cells, 9(4), 581-94.

116. Moon, J. H., Lee, J. R., Jee, B. C., Suh, C. S., Kim, S. H., Lim, H. J., et al. (2008). Successful vitrification of human amnion-derived mesenchymal stem cells. Human Reproduction, 23(8), 1760-70.

117. Stadler, G., Hennerbichler, S., Lindenmair, A., Peterbauer, A., Hofer, K., van Griensven, M., et al. (2008). Phenotypic shift of human amniotic epithelial cells in culture is associated with reduced osteogenic differentiation in vitro. Cytotherapy, 10(7), 743-52.

118. Diaz-Prado, S., Muinos-Lopez, E., Hermida-Gomez, T., RendalVazquez, M. E., Fuentes-Boquete, I., de Toro, F. J., et al. (2010). Multilineage differentiation potential of cells isolated from the human amniotic membrane. Journal of Cellular Biochemistry, 111(4), 846-57.

119. Jaramillo-Ferrada, P. A., Wolvetang, E. J., \& Cooper-White, J. J. (2012). Differential mesengenic potential and expression of stem cell-fate modulators in mesenchymal stromal cells from human-term placenta and bone marrow. Journal of Cellular Physiology, 227(9), 3234-42.

120. Fatimah, S. S., Tan, G. C., Chua, K., Fariha, M. M., Tan, A. E., \& Hayati, A. R. (2013). Stemness and angiogenic gene expression changes of serial-passage human amnion mesenchymal cells. Microvascular Research, 86, 21-9.

121. Tamagawa, T., Ishiwata, I., \& Nakamura, Y. (2005). Differentiation of human amniotic membrane cells into osteoblasts in vitro. Human Cell, 18(4), 191-5.

122. Wolbank, S., Stadler, G., Peterbauer, A., Gillich, A., Karbiener, M., Streubel, B., et al. (2009). Telomerase immortalized human amnion- and adipose-derived mesenchymal stem cells: maintenance of differentiation and immunomodulatory characteristics. Tissue Engineering Part A, 15(7), 1843-54.

123. In 't Anker, P. S., Scherjon, S. A., Kleijburg-van der Keur, C., de Groot-Swings, G. M., Claas, F. H., Fibbe, W. E., et al. (2004). Isolation of mesenchymal stem cells of fetal or maternal origin from human placenta. Stem Cells, 22(7), 1338-45.

124. Igura, K., Zhang, X., Takahashi, K., Mitsuru, A., Yamaguchi, S., \& Takashi, T. A. (2004). Isolation and characterization of mesenchymal progenitor cells from chorionic villi of human placenta. Cytotherapy, 6(6), 543-53.

125. Wulf, G. G., Viereck, V., Hemmerlein, B., Haase, D., Vehmeyer, K., Pukrop, T., et al. (2004). Mesengenic progenitor cells derived from human placenta. Tissue Engineering, 10(7-8), 1136-47.

126. Kadam, S., Muthyala, S., Nair, P., \& Bhonde, R. (2010). Human placenta-derived mesenchymal stem cells and islet- like cell clusters generated from these cells as a novel source for stem cell therapy in diabetes. The Review of Diabetic Studies, 7(2), 168-82.

127. Fariha, M. M., Chua, K. H., Tan, G. C., Tan, A. E., \& Hayati, A. R. (2011). Human chorion-derived stem cells: changes in stem cell properties during serial passage. Cytotherapy, 13(5), 582-93.

128. Koo, B. K., Park, I. Y., Kim, J., Kim, J. H., Kwon, A., Kim, M., et al. (2012). Isolation and characterization of chorionic mesenchymal stromal cells from human full term placenta. Journal of Korean Medical Science, 27(8), 857-63.

129. Abumaree, M. H., Al Jumah, M. A., Kalionis, B., Jawdat, D., Al Khaldi, A., AlTalabani, A. A., et al. (2013). Phenotypic and functional characterization of mesenchymal stem cells from chorionic villi of human term placenta. Stem Cell Reviews, 9(1), 16-31.

130. Ha, J. W., Kim, J. A., \& Ha, C. W. (2012). Do the fibroblasts contained in early passage MSC population adversely affect the characteristics of stem cell population obtained from human placenta? International Journal Stem Cells, 5(2), 89-95.

131. Zhang, X., Soda, Y., Takahashi, K., Bai, Y., Mitsuru, A., Igura, K., et al. (2006). Successful immortalization of mesenchymal progenitor cells derived from human placenta and the differentiation abilities of immortalized cells. Biochemical and Biophysical Research Communications, 351(4), 853-9.

132. Resca, E., Zavatti, M., Bertoni, L., Maraldi, T., De Biasi, S., Pisciotta, A., et al. (2013). Enrichment in c-Kit+ enhances mesodermal and neural differentiation of human chorionic placental cells. Placenta, 34(7), 526-35.

133. Poloni, A., Rosini, V., Mondini, E., Maurizi, G., Mancini, S., Discepoli, G., et al. (2008). Characterization and expansion of mesenchymal progenitor cells from first-trimester chorionic villi of human placenta. Cytotherapy, 10(7), 690-7.

134. Meraviglia, V., Vecellio, M., Grasselli, A., Baccarin, M., Farsetti, A., Capogrossi, M. C., et al. (2012). Human chorionic villus mesenchymal stromal cells reveal strong endothelial conversion properties. Differentiation, 83(5), 260-70.

135. Sung, H. J., Hong, S. C., Yoo, J. H., Oh, J. H., Shin, H. J., Choi, I. Y., et al. (2010). Stemness evaluation of mesenchymal stem cells from placentas according to developmental stage: comparison to those from adult bone marrow. Journal of Korean Medical Science, 25(10), 1418-26.

136. Hayati, A. R., Nur Fariha, M. M., Tan, G. C., Tan, A. E., \& Chua, K. (2011). Potential of human decidua stem cells for angiogenesis and neurogenesis. Archives of Medical Research, 42(4), 291-300.

137. Zhong, Z. N., Zhu, S. F., Yuan, A. D., Lu, G. H., He, Z. Y., Fa, Z. Q., et al. (2012). Potential of placenta-derived mesenchymal stem cells as seed cells for bone tissue engineering: preliminary study of osteoblastic differentiation and immunogenicity. Orthopedics, 35(9), 779-88.

138. Dimitrov, R., Kyurkchiev, D., Timeva, T., Yunakova, M., Stamenova, M., Shterev, A., et al. (2010). First-trimester human decidua contains a population of mesenchymal stem cells. Fertility and Sterility, 93(1), 210-9.

139. Fukuchi, Y., Nakajima, H., Sugiyama, D., Hirose, I., Kitamura, T., \& Tsuji, K. (2004). Human placenta-derived cells have mesenchymal stem/progenitor cell potential. Stem Cells, 22(5), 649-58.

140. Yen, B. L., Huang, H. I., Chien, C. C., Jui, H. Y., Ko, B. S., Yao, M., et al. (2005). Isolation of multipotent cells from human term placenta. Stem Cells, 23(1), 3-9.

141. Musina, R. A., Bekchanova, E. S., Belyavskii, A. V., \& Sukhikh, G. T. (2006). Differentiation potential of mesenchymal stem cells of different origin. Bulletin of Experimental Biology and Medicine, 141(1), 147-51.

142. Jones, B. J., Brooke, G., Atkinson, K., \& McTaggart, S. J. (2007). Immunosuppression by placental indoleamine 2,3-dioxygenase: a role for mesenchymal stem cells. Placenta, 28(11-12), 1174-81.

143. Li, D., Wang, G. Y., Dong, B. H., Zhang, Y. C., Wang, Y. X., \& Sun, B. C. (2007). Biological characteristics of human placental 
mesenchymal stem cells and their proliferative response to various cytokines. Cells, Tissues, Organs, 186(3), 169-79.

144. Barlow, S., Brooke, G., Chatterjee, K., Price, G., Pelekanos, R., Rossetti, T., et al. (2008). Comparison of human placenta- and bone marrow-derived multipotent mesenchymal stem cells. Stem Cells and Development, 17(6), 1095-107.

145. Ostanin, A. A., Petrovskiy, Y. L., Shevela, E. Y., Kurganova, E. V., Drobinskaja, A. N., Dobryakova, O. B., et al. (2008). A new approach to evaluation of osteogenic potential of mesenchymal stromal cells. Bulletin of Experimental Biology and Medicine, 146(4), 534-9.

146. Montesinos, J. J., Flores-Figueroa, E., Castillo-Medina, S., FloresGuzman, P., Hernandez-Estevez, E., Fajardo-Orduna, G., et al. (2009). Human mesenchymal stromal cells from adult and neonatal sources: comparative analysis of their morphology, immunophenotype, differentiation patterns and neural protein expression. Cytotherapy, 11(2), 163-76.

147. Castrechini, N. M., Murthi, P., Gude, N. M., Erwich, J. J., Gronthos, S., Zannettino, A., et al. (2010). Mesenchymal stem cells in human placental chorionic villi reside in a vascular Niche. Placenta, 31(3), 203-12.

148. Semenov, O. V., Koestenbauer, S., Riegel, M., Zech, N., Zimmermann, R., Zisch, A. H., et al. (2010). Multipotent mesenchymal stem cells from human placenta: critical parameters for isolation and maintenance of stemness after isolation. American Journal of Obstetrics and Gynecology, 202(2), 193 e1-193 e13.

149. Sun, N. Z., \& Ji, H. (2012). In vitro differentiation of osteocytes and adipocytes from human placenta-derived cells. Journal of International Medical Research, 40(2), 761-7.

150. Sabapathy, V., Ravi, S., Srivastava, V., Srivastava, A., \& Kumar, S. (2012). Long-term cultured human term placenta-derived mesenchymal stem cells of maternal origin displays plasticity. Stem Cells International, 2012, 174328.

151. Vellasamy, S., Sandrasaigaran, P., Vidyadaran, S., George, E., \& Ramasamy, R. (2012). Isolation and characterisation of mesenchymal stem cells derived from human placenta tissue. World Journal Stem Cells, 4(6), 53-61.

152. Ho, P. J., Yen, M. L., Tang, B. C., Chen, C. T., \& Yen, B. L. (2013). $\mathrm{H} 2 \mathrm{O} 2$ accumulation mediates differentiation capacity alteration, but not proliferative decline, in senescent human fetal mesenchymal stem cells. Antioxidants and Redox Signaling, 18(15), 1895-905.

153. Guillaume-Gentil, O., Semenov, O. V., Zisch, A. H., Zimmermann, R., Voros, J., \& Ehrbar, M. (2011). pH-controlled recovery of placenta-derived mesenchymal stem cell sheets. Biomaterials, 32(19), 4376-84

154. Zhu, Z., Liu, Z., Liu, J., Bi, M., Yang, T., \& Wang, J. (2014). Proteomic profiling of human placenta-derived mesenchymal stem cells upon transforming LIM mineralization protein-1 stimulation. Cytotechnology. doi:10.1007/s10616-013-3684-x.

155. Lu, L. L., Liu, Y. J., Yang, S. G., Zhao, Q. J., Wang, X., Gong, W., et al. (2006). Isolation and characterization of human umbilical cord mesenchymal stem cells with hematopoiesis-supportive function and other potentials. Haematologica, 91(8), 1017-26.

156. Karahuseyinoglu, S., Cinar, O., Kilic, E., Kara, F., Akay, G. G., Demiralp, D. O., et al. (2007). Biology of stem cells in human umbilical cord stroma: in situ and in vitro surveys. Stem Cells, 25(2), 319-31.

157. Girdlestone, J., Limbani, V. A., Cutler, A. J., \& Navarrete, C. V. (2009). Efficient expansion of mesenchymal stromal cells from umbilical cord under low serum conditions. Cytotherapy, 11(6), $738-48$.

158. La Rocca, G., Anzalone, R., Corrao, S., Magno, F., Loria, T., Lo Iacono, M., et al. (2009). Isolation and characterization of Oct-4+/ HLA-G+ mesenchymal stem cells from human umbilical cord matrix: differentiation potential and detection of new markers. Histochemistry and Cell Biology, 131(2), 267-82.
159. Penolazzi, L., Vecchiatini, R., Bignardi, S., Lambertini, E., Torreggiani, E., Canella, A., et al. (2009). Influence of obstetric factors on osteogenic potential of umbilical cordderived mesenchymal stem cells. Reproductive Biology and Endocrinology, 7, 106.

160. Caballero, M., Reed, C. R., Madan, G., \& van Aalst, J. A. (2010). Osteoinduction in umbilical cord- and palate periosteum-derived mesenchymal stem cells. Annals of Plastic Surgery, 64(5), 605-9.

161. Hartmann, I., Hollweck, T., Haffner, S., Krebs, M., Meiser, B., Reichart, B., et al. (2010). Umbilical cord tissue-derived mesenchymal stem cells grow best under GMP-compliant culture conditions and maintain their phenotypic and functional properties. Journal of Immunological Methods, 363(1), 80-9.

162. Hsieh, J. Y., Fu, Y. S., Chang, S. J., Tsuang, Y. H., \& Wang, H. W. (2010). Functional module analysis reveals differential osteogenic and stemness potentials in human mesenchymal stem cells from bone marrow and Wharton's jelly of umbilical cord. Stem Cells and Development, 19(12), 1895-910.

163. Nekanti, U., Mohanty, L., Venugopal, P., Balasubramanian, S., Totey, S., \& Ta, M. (2010). Optimization and scale-up of Wharton's jelly-derived mesenchymal stem cells for clinical applications. Stem Cell Research, 5(3), 244-54.

164. Cheng, H., Qiu, L., Ma, J., Zhang, H., Cheng, M., Li, W., et al. (2011). Replicative senescence of human bone marrow and umbilical cord derived mesenchymal stem cells and their differentiation to adipocytes and osteoblasts. Molecular Biology Reports, $38(8), 5161-8$

165. Montanucci, P., Basta, G., Pescara, T., Pennoni, I., Di Giovanni, F., $\&$ Calafiore, R. (2011). New simple and rapid method for purification of mesenchymal stem cells from the human umbilical cord Wharton jelly. Tissue Engineering Part A, 17(21-22), 2651-61.

166. Tsagias, N., Koliakos, I., Karagiannis, V., Eleftheriadou, M., \& Koliakos, G. G. (2011). Isolation of mesenchymal stem cells using the total length of umbilical cord for transplantation purposes. Transfusion Medicine, 21(4), 253-61.

167. Chen, H. C., Lee, Y. S., Sieber, M., Lu, H. T., Wei, P. C., Wang, C. N., et al. (2012). MicroRNA and messenger RNA analyses of mesenchymal stem cells derived from teeth and the Wharton jelly of umbilical cord. Stem Cells and Development, 21(6), 911-22.

168. Gong, W., Han, Z., Zhao, H., Wang, Y., Wang, J., Zhong, J., et al. (2012). Banking human umbilical cord-derived mesenchymal stromal cells for clinical use. Cell Transplantation, 21(1), 207-16.

169. Salehinejad, P., Alitheen, N. B., Nematollahi-Mahani, S. N., Ali, A. M., Omar, A. R., Janzamin, E., et al. (2012). Effect of culture media on expansion properties of human umbilical cord matrix-derived mesenchymal cells. Cytotherapy, 14(8), 948-53.

170. Christodoulou, I., Kolisis, F. N., Papaevangeliou, D., \& Zoumpourlis, V. (2013). Comparative evaluation of human mesenchymal stem cells of fetal (Wharton's jelly) and adult (adipose tissue) Origin during prolonged in vitro expansion: considerations for cytotherapy. Stem Cells International, 2013, 246134.

171. Corotchi, M. C., Popa, M. A., Remes, A., Sima, L. E., Gussi, I., \& Lupu Plesu, M. (2013). Isolation method and xeno-free culture conditions influence multipotent differentiation capacity of human Wharton's jelly-derived mesenchymal stem cells. Stem Cell Research \& Therapy, 4(4), 81.

172. Huang, S., Feng, C., Wu, Y., Yang, S., Ma, K., Wu, X., et al. (2013). Dissimilar characteristics of umbilical cord mesenchymal stem cells from donors of different ages. Cell and Tissue Banking, 14(4), 707-13.

173. Kouroupis, D., Churchman, S. M., English, A., Emery, P., Giannoudis, P. V., McGonagle, D., et al. (2013). Assessment of umbilical cord tissue as a source of mesenchymal stem cell/endothelial cell mixtures for bone regeneration. Regenerative Medicine, 8(5), 569-81.

174. La Rocca, G., Lo Iacono, M., Corsello, T., Corrao, S., Farina, F., \& Anzalone, R. (2013). Human Wharton's jelly mesenchymal stem 
cells maintain the expression of key immunomodulatory molecules when subjected to osteogenic, adipogenic and chondrogenic differentiation in vitro: new perspectives for cellular therapy. Current Stem Cell Research \& Therapy, 8(1), 100-13.

175. Patel, A. N., Vargas, V., Revello, P., \& Bull, D. A. (2013). Mesenchymal stem cell population isolated from the subepithelial layer of umbilical cord tissue. Cell Transplantation, 22(3), 513-9.

176. Chen, G., Yue, A., Ruan, Z., Yin, Y., Wang, R., Ren, Y., et al. (2014). Monitoring the biology stability of human umbilical cordderived mesenchymal stem cells during long-term culture in serumfree medium. Cell Tissue Bank.

177. Gao, W., Zhang, H., Chang, G., Xie, Z., Wang, H., Ma, L., et al. (2014). Decreased intracellular $\mathrm{pH}$ induced by cariporide differentially contributes to human umbilical cord-derived mesenchymal stem cells differentiation. Cellular Physiology and Biochemistry, 33(1), 185-94.

178. Hendijani, F., Sadeghi-Aliabadi, H., \& Haghjooy Javanmard, S. (2014). Comparison of human mesenchymal stem cells isolated by explant culture method from entire umbilical cord and Wharton's jelly matrix. Cell and Tissue Banking. doi:10.1007/s10561-014-9425-1.

179. Pan, H., Lan, J., Luo, X., Gao, J., Xie, X., \& Guo, H. (2014). Biologic properties of gadolinium diethylenetriaminepentaacetic acid-labeled and PKH26-labeled human umbilical cord mesenchymal stromal cells. Cytotherapy, 16(1), 74-83.

180. Lindenmair, A., Nurnberger, S., Stadler, G., Meinl, A., Hackl, C., Eibl, J., et al. (2014). Intact human amniotic membrane differentiated towards the chondrogenic lineage. Cell and Tissue Banking, 15(2), 213-25.

181. Mennan, C., Wright, K., Bhattacharjee, A., Balain, B., Richardson, J., \& Roberts, S. (2013). Isolation and characterisation of mesenchymal stem cells from different regions of the human umbilical cord. Biomed Research International, 2013, 916136.

182. Santos, J. M., Barcia, R. N., Simoes, S. I., Gaspar, M. M., Calado, S., Agua-Doce, A., et al. (2013). The role of human umbilical cord tissue-derived mesenchymal stromal cells $(\mathrm{UCX}(\mathrm{R}))$ in the treatment of inflammatory arthritis. Journal of Translational Medicine, 11, 18.

183. Trivanovic, D., Kocic, J., Mojsilovic, S., Krstic, A., Ilic, V., Djordjevic, I. O., et al. (2013). Mesenchymal stem cells isolated from peripheral blood and umbilical cord Wharton's jelly. Srpski Arhiv za Celokupno Lekarstvo, 141(3-4), 178-86.

184. Ramis, J. M., Rubert, M., Vondrasek, J., Gaya, A., Lyngstadaas, S. P., \& Monjo, M. (2012). Effect of enamel matrix derivative and of proline-rich synthetic peptides on the differentiation of human mesenchymal stem cells toward the osteogenic lineage. Tissue Engineering Part A, 18(11-12), 1253-63.

185. Guan, F., Ma, S., Shi, X., Ma, X., Chi, L., Liang, S., et al. (2014). Biocompatibility of nano-hydroxyapatite/Mg-Zn-Ca alloy composite scaffolds to human umbilical cord mesenchymal stem cells from Wharton's jelly in vitro. Science China. Life Sciences, 57(2), 181-7.

186. Majore, I., Moretti, P., Stahl, F., Hass, R., \& Kasper, C. (2011). Growth and differentiation properties of mesenchymal stromal cell populations derived from whole human umbilical cord. Stem Cell Reviews, 7(1), 17-31.

187. Struys, T., Moreels, M., Martens, W., Donders, R., Wolfs, E., \& Lambrichts, I. (2011). Ultrastructural and immunocytochemical analysis of multilineage differentiated human dental pulp- and umbilical cord-derived mesenchymal stem cells. Cells, Tissues, Organs, 193(6), 366-78.

188. Witkowska-Zimny, M., Walenko, K., Walkiewicz, A. E., Pojda, Z., Przybylski, J., \& Lewandowska-Szumiel, M. (2012). Effect of substrate stiffness on differentiation of umbilical cord stem cells. Acta Biochimica Polonica, 59(2), 261-4.

189. Karadas, O., Yucel, D., Kenar, H., Torun Kose, G., \& Hasirci, V. (2012). Collagen scaffolds with in situ-grown calcium phosphate for osteogenic differentiation of Wharton's jelly and menstrual blood stem cells. Journal of Tissue Engineering and Regenerative Medicine, 8(7), 534-45.

190. Detsch, R., Alles, S., Hum, J., Westenberger, P., Sieker, F., Heusinger, D., et al. (2014). Osteogenic differentiation of umbilical cord and adipose derived stem cells onto highly porous 45S5 Bioglass -based scaffolds. J Biomed Mater Res A.

191. Qian, H., Zhang, X., Xu, W., Zhu, W., Cao, H., Chen, Y., et al. (2010). Lentivirus-modified human umbilical cord mesenchymal stem cells maintain their pluripotency. Biotechnology and Applied Biochemistry, 55(1), 53-62. 